\title{
Culinary Temperature Variably Affects the Antioxidant Content of Some Local Spices and Green Herbs
}

\author{
Choumessi T. Aphrodite ${ }^{1, a, *}$, Sonchieu Jean ${ }^{2, b}$, Yong D. Kuoh ${ }^{2, c}$, Tenyung E. Eyen ${ }^{2, d}$, Mbouh Mariama ${ }^{1, e}$, \\ Nantia A. Edouard ${ }^{1, f}$
}

${ }^{I}$ Department of Biochemistry, Faculty of Science, The University of Bamenda, 39 Bambili, Cameroon

${ }^{2}$ Department of Social Economy and Family Management, HTTTC, The University of Bamenda, 39 Bambili, Cameroon *Corresponding author

\begin{tabular}{l|l} 
A R T I C L E I N F O & A B S T R A C T \\
\hline $\begin{array}{l}\text { Research Article } \\
\text { Received : 13/10/2020 }\end{array}$ & $\begin{array}{l}\text { Spices and herbs are groups of vegetables with important properties for human health and food } \\
\text { industries. They are generally consumed in cooked recipes and such treatment may affect the } \\
\text { content of vital components such antioxidants. This study aimed at evaluating the effect of the } \\
\text { cooking temperatures on total phenolics, flavonoids and vitamin C of some spices and herbs used } \\
\text { in the locality of Bamenda, Cameroon. Briefly, the most consumed spices and herbs were selected } \\
\text { through structured questionnaires administered to individuals involved in their consumption and } \\
\text { selling. Thereafter, samples were collected and subjected to different boiling treatments and the } \\
\text { levels of the antioxidants (flavonoids, phenols and vitamin C) were determined. Results showed } \\
\text { that almost half the participants }(48 \%) \text { used Parsley, Basil, White pepper, Njansa, Mint and African } \\
\text { nutmeg mainly for flavoring and medicinal purposes. The cooking temperature of } 65^{\circ} \mathrm{C} \text { increased } \\
\text { total phenolics and flavonoids in spices (Mint, White pepper, Njangsa and African nutmeg) and } \\
\left.\text { herbs (Parsley, Basil) while higher heat treatments (75 and } 85^{\circ} \mathrm{C}\right) \text { lowered the content of these } \\
\text { pytochemicals. Boiling of spices or herbs significantly and temperature dependently reduced the } \\
\text { vitamin C content in all spice and herb samples with respect to the control raw samples. Summarily, } \\
\text { the moderate boiling }\left(65^{\circ} \mathrm{C}\right) \text { treatment used by the local populations favors release of total phenolics } \\
\text { and flavonoids though with some reducing effect on vitamin C. }\end{array}$ \\
$\begin{array}{l}\text { Keywords: } \\
\text { Antioxidants }\end{array}$ \\
$\begin{array}{l}\text { Herbs } \\
\text { Spices } \\
\text { Medicinal benefits }\end{array}$
\end{tabular}

(iD https://orcid.org/0000-0002-0962-3242 iD https://orcid.org/0000-0001-9197-7893 (iD) https://orcid.org/0000-0003-2944-4425

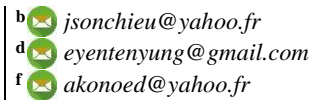

(iD) https://orcid.org/0000-0002-9030-0685
(iD) https://orcid.org/0000-0003-4952-7172
(iD) https://orcid.org/0000-0001-7013-2373

\section{Introduction}

Spices are dried seed, fruit, root, bark or vegetative substance used nutritional as a food additive for the purpose of flavoring and sometimes as preservative as they can kill or prevent the growth of bacteria. Herbs may be defined as leaves of aromatic plants used to impart flavour and odour to foods. However, the terms spice and herb are commonly used interchangeably (Adamson, 2004; Peter, 2012). Spices constitute one of food elements used worldwide with constant demand. The global market of spices and herbs was estimated at $\$ 11.5$ billion in 2019 and will increase to $\$ 14.5$ billion in 2025 with a compound annual growth rate (CAGR) of 3.89\% (Shahbandeh, 2020). Spices are mainly used to increase food palatability, but do have medicinal and preservation properties. These properties of spices mainly stemmed from their abundant content in bioactive compounds especially antioxidant including vitamins, sulfur-containing compounds, alkaloids and phenolic compounds (Gottardi et al., 2016; Yashin et al., 2017; Pehlivan et al., 2018; Mohammed et al., 2019). Phenolic compounds are a main class of secondary metabolites in plants and comprise many classes with the main dietary ones being phenolic acids, flavonoids, and tannins. Thanks to their structural content in hydroxyl groups, and the nature of substitutions on the aromatic rings, phenolic compounds scavenge free radicals, donate hydrogen atoms, electrons, or chelate metal cations (Minatel et al., 2017/). Polyphenols from the diet have been shown to reduce the risk of infectious, degenerative and chronic diseases. Vitamin $\mathrm{C}$ thanks to its antioxidant ability has been implicated in the prevention and/or management of many health conditions such common cold, boosting of the immune system, and 
infectious, metabolic and neurodegenerative diseases (Ozcan et al., 2014; Lee, 2019). In food industries, antioxidants control rancidity development, retard the formation of toxic oxidation products, maintain nutritional quality, and extend the shelf-life of products (Lourenço et al., 2019). However, because of safety concerns of the synthetic antioxidants, more interest is now directed towards antioxidants from natural sources (Sarkar, 2016; Sevindik et al., 2017; Mohammed et al., 2020).

Cooking is an indispensable prerequisite in order to obtain safe and high-quality food products. Cooked vegetables have better hygienic quality and due to chemical reactions during cooking, they are better digestible and have an increased nutritional value (EUFIC, 2010). Cooking is necessary for most vegetables and may cause positive or negative changes in the compositions or bioavailability of biochemicals, including the different nutrients in vegetables (Miglio et al., 2007; Karimiankhosroshahi et al., 2015). In rural areas, particularly in developing countries, most of the food preparation techniques are still traditional involving implication of water, and this highly affects the content of nutrients including antioxidants (Habwe and Walingo, 2008). For instance, vitamin $\mathrm{C}$ due to its water solubility might leach out into the water during cooking methods such as boiling (Lee et al., 2018). For antioxidants such as phenolics and flavonoids, cooking has shown varying effects depending on the nature of vegetable, the cooking method, the cooking temperature and duration (Song et al., 2013; Mastura et al., 2017; Hwang, 2017). This study was therefore designed to assess the effects of culinary temperature on commonly consumed spices and herbs from Bamenda area of the North West region of Cameroon.

\section{Materials and Methods}

\section{Participants}

The target population of the study was made up of all the spices or herbs consumers and sellers in Bamenda food market. The spices or herbs sellers were identified by the fact that they have been in the business for at least 6 months and have experience on the use of spices and herbs. The consumers were those using spices or herbs daily in their activities, like food vendors, house wives for food preparations. Participants were freely taken into the study without any obligation. The participants were assured of confidentiality of their information and respondents who were in doubt about giving out information were assured of anonymity of their identity as evidenced in the questionnaires. Moreover, participants signed informed consent attesting their agreement to take part in the study and the research received authorization from public health authorities (Reference $\mathrm{N}^{\circ}$ : 119/ATT/NWR/RDPH/BRIGAD).

\section{Questionnaire Setting and Administration}

A structured questionnaire was developed on the aspects including job specificity (seller, consumer of spices or herbs), type of spices or herbs consumed/sold, method of spice or herb treatment (raw, boiling, time and temperatures of boiling), the uses of spices and the health benefits of spices or herbs. The questionnaire was validated through pre-testing on ten randomly chosen volunteers.
One hundred questionnaires were administered during the business days (Monday to Saturday) of the Bamenda food market from $11 \mathrm{am}$ when sellers and consumers were all around. The visit was unannounced to ensure the accuracy of the respondent answers. The respondents who were unable to read and/or write were helped out by the investigator.

\section{Samples Collection and Treatment}

For the assessment of the effect of temperature on antioxidant content of the spices or herbs, samples of the most used/sold spices or herbs, namely mint (Mentha piperita L.), parsley (Petroselinum crispum (Mill.) Fuss), basil (Ocimum basilicum L.), white pepper (Piper nigrum L.), njangsa (Ricinodendron heudelotii (Baill.) Heckel) and African nutmeg (Monodora myristica (Gaertn.) Dunal) were collected from Bamenda food market and taken to the laboratory for subsequent treatment and analyses. Two grams of spice or herb samples were grinded and extracted by stirring intermittently in $40 \mathrm{~mL}$ distilled water for 30 minutes at room temperature for the control treatment, while for the experimental treatments the extractions were done at temperatures of $65^{\circ} \mathrm{C}, 75^{\circ} \mathrm{C}$ and $85^{\circ} \mathrm{C}$, respectively. These particular temperatures were obtained from the questionnaire findings and adapted to laboratory experimental setup. After extraction, the mixture was filtered using a Whatmann \#4 filter paper to obtain the extract used for subsequent tests.

\section{Chemicals}

Aluminum chloride $\left(\mathrm{AlCl}_{3}\right)$ and potassium acetate were obtained from Burgoynes and Co. (Mumbai, India) and pure methanol was from Labal Chemie (Mumbai, India). Sodium carbonate $\left(\mathrm{Na}_{2} \mathrm{CO}_{3}\right)$, Quercetin, Folin Ciocalteu's (FC) reagent and Gallic acid were purchased from Sigma Aldrich (France). Other chemicals were of analytical grade.

\section{Quantification of Total Phenolics}

The total phenolic content of the spice or herb samples was determined by Folin Ciocalteu's method as earlier described (Nantia et al., 2018). Summarily, spice or herb extracts $(0.2 \mathrm{~mL})$ were placed in respective tubes, then 0.9 $\mathrm{mL}$ and $0.1 \mathrm{~mL}$ of distilled water and of Folin Ciocalteu (FC) reagent, respectively were added and the mixture incubated for $10 \mathrm{~min}$ at room temperature. Thereafter, 1 $\mathrm{mL}$ of $5 \%$ Sodium carbonate and $2.5 \mathrm{~mL}$ of distilled water were added and the mixture was incubated for $2 \mathrm{hrs}$ at room temperature. The absorbance of the tube was read at $750 \mathrm{~nm}$ against the blank and the total phenolics were expressed as garlic acid equivalent in $\mu \mathrm{g} / \mathrm{g}$ of sample.

\section{Quantification of Flavonoids}

The flavonoid content in spice or herb samples was determined using the aluminum chloride colorimetric method as described by Nantia et al. (2018). One milliliter of $95 \%$ methanol and $0.1 \mathrm{ml}$ of $1 \mathrm{M}$ potassium acetate were added into $0.2 \mathrm{~mL}$ of spice or herb extracts and the mixture was incubated for $15 \mathrm{~min}$ at room temperature. Then, $0.1 \mathrm{~mL}$ of $10 \%$ aluminum chloride was added and the mixture incubated once more for $1 \mathrm{hr}$ at room temperature. After addition of $2.1 \mathrm{~mL}$ of distilled water, the absorbencies were recorded at $415 \mathrm{~nm}$ against the blank and the flavonoid content was expressed as quercetin equivalent in $\mu \mathrm{g} / \mathrm{g}$ of sample. 


\section{Estimation of Vitamin C}

The vitamin $\mathrm{C}$ content was estimated by a redox titration method using iodine as previously reported (Nantia et al., 2018) with slight modification. Briefly, 5mL of the spice/herb extract was pipetted into a conical flask, then $37.5 \mathrm{~mL}$ of distilled water and $1 \mathrm{~mL}$ of starch indicator solution were added. The sample was titrated with $5 \mathrm{mM}$ iodine solution till the first permanent trace of a blue-black color due to the starch-iodine complex was observed. The titration was repeated with 3 more aliquots of sample extract until concordant results were obtained.

\section{Data Analysis}

Collected data from the field were checked, input and descriptive analysis performed using the statistical package SPSS (Statistical Package for Social Science) version 21.0. Laboratory data were assessed using one-way analysis of variance with the Student Newman Keuls test as posthoc test.

\section{Results}

\section{Spices and Herbs Sold or Used}

The spices and herbs were generally sold or consumed by the participants in combinations (Table 1). The main combinations of spices/herbs were the group of Parsley, Basil, White pepper, Njansa, Mint and African nutmeg sold or consumed by $48 \%$ of the populations followed by those of Parsley, Basil, White pepper, Njansa and African nutmeg, and Basil, Black Pepper, Njansa, Mint and African nutmeg with the percentages of 24 and $20 \%$, respectively.

\section{Usages of Spices or Herbs}

The highest proportion of spices or herbs was used by the respondents for food flavoring (47\%) or for flavoring and medicinal purposes $(42 \%)$ (Table 2). Some other usages of spices included flavoring, medicine and cosmetics (4\%), condiment $(2 \%)$, condiments, flavoring and medicine $(2 \%)$ and condiments, flavoring, medicine and tea $(1 \%)$.

Culinary and Heat Treatment of Spices or Herbs

All the participants used spices or herbs in the raw or cooked form though at different levels of culinary or heat treatment (Table 3). A clear majority of the participants (72\%) liked to consume cooked spices/herbs while $20 \%$ consumed them well done, and a little portion (8.0\%) liked the raw form. In cooking their spices or herbs, $46 \%$ used high heat, while 32 and 14\% used moderate and medium heat, respectively. The moderate, medium and high heats used by the participants were experimentally equivalent to 65,75 and $85^{\circ} \mathrm{C}$, respectively. The participants cooked their spices or herbs for an average duration of $30 \mathrm{~min}$.

\section{Phenols}

As compared to the raw samples, all temperatures showed positive and significant $(\mathrm{P}<0.05)$ effects on the release of total phenolics from spice or herb samples with the exception of Parsley (Table 4). For Mint, Parsley, Basil, White pepper and Njangsa samples, the increase of temperature from 65 to $85^{\circ} \mathrm{C}$ inversely affected the phenolic contents while the temperature showed a biphasic effect with African nutmeg with highest levels of phenolics noted with the boiling at $85^{\circ} \mathrm{C}$. Globally, the boiling spices or herbs at the temperature of $65^{\circ} \mathrm{C}$ highly released phenolics as compared to other temperatures.

\section{Flavonoids}

In general, the boiling temperatures significantly increased $(\mathrm{P}<0.05)$ the flavonoid levels of spices or herbs though the highest temperature $\left(85^{\circ} \mathrm{C}\right)$ seemed to reduce these phytochemical levels as compare to the other temperatures (Table 5). The increase in the temperature showed a bellshaped effect on the release of flavonoids from samples of Mint, Parsley, Basil, White pepper, and Njangsa. But the flavonoid content of African nutmeg displayed a temperature dependent effect release. Globally, with relative to the other temperatures, boiling at $65^{\circ} \mathrm{C}$ showed highest effect in releasing flavonoids from spices or herbs.

\section{Vitamin C}

With the exception of White pepper, vitamin $\mathrm{C}$ levels of the investigated spices or herbs were severely negatively affected by the temperatures when compared to the raw (control) samples (Table 6). Globally, boiling significantly $(\mathrm{P}<0.05)$ and temperature dependently reduced the vitamin $\mathrm{C}$ in spice or herb samples with respect to the control samples. Boiling spices or herbs at the highest temperature $\left(85^{\circ} \mathrm{C}\right)$ led to the lowest level of vitamin $\mathrm{C}$ as compared to the other temperatures.

Table 1 . Spices and herbs sold/used by the participants.

\begin{tabular}{|c|c|c|}
\hline Species consumed/sold & Frequency & Percent \\
\hline Parsley, Basil, White pepper, Njansa, Mint, African nutmeg & 48 & 48 \\
\hline Parsley, Basil, White Pepper, Njansa, African nutmeg & 24 & 24 \\
\hline Parsley, White Pepper, Mint, Ginger, Garlic, African nutmeg & 20 & 20 \\
\hline Parsley, Basil, White Pepper, Njansa, Garlic & 4 & 4 \\
\hline Basil, Black Pepper, Njansa, Mint, African nutmeg & 2 & 2 \\
\hline Parsley, White Pepper, Black Pepper, Njansa, African nutmeg & 2 & 2 \\
\hline
\end{tabular}

Table 2. Usages of spices or herbs by the respondents.

\begin{tabular}{l|cc}
\hline \multicolumn{1}{c|}{ Usage of spices } & Frequency & Percent \\
\hline Flavoring & 47 & 47 \\
Flavoring and medicine & 42 & 42 \\
Flavoring, medicine and cosmetics & 4 & 4 \\
Condiments & 2 & 2 \\
Condiments, flavoring, medicine, tea and cosmetics & 2 & 2 \\
Condiments, flavoring and medicine & 2 & 2 \\
Condiments, flavoring, medicine and tea & 1 & 1 \\
\hline
\end{tabular}


Table 3. Culinary and heat treatment of spices or herbs.

\begin{tabular}{l|cc}
\hline \multicolumn{1}{c|}{ State of food consumption } & Frequency & Percent \\
\hline Raw & 8 & 8 \\
Cooked & 72 & 72 \\
Well Done & 20 & 20 \\
Cooking Temperature & Frequency & Percent \\
Moderate heat $\left(65^{\circ} \mathrm{C}\right)$ & 32 & 32 \\
Medium Heat $\left(75^{\circ} \mathrm{C}\right)$ & 14 & 14 \\
High Heat $\left(85^{\circ} \mathrm{C}\right)$ & 46 & 46 \\
\hline
\end{tabular}

Table 4. Phenolic content of spices or herbs.

\begin{tabular}{l|cccc}
\hline \multirow{2}{*}{ Sample } & \multicolumn{4}{c}{ Phenolic compounds $(\mu$ g garlic acid equivalent /g of spice or herb) } \\
\cline { 2 - 5 } & \multicolumn{1}{c|}{ Control } & $65^{\circ} \mathrm{C}$ & $75^{\circ} \mathrm{C}$ & $85^{\circ} \mathrm{C}$ \\
\hline Mint & $18.81 \pm 0.28^{\mathrm{a}}$ & $65.77 \pm 0.19^{\mathrm{b}}$ & $63.20 \pm 1.42^{\mathrm{b}}$ & $60.68 \pm 14.59^{\mathrm{b}}$ \\
Parsley & $36.49 \pm 0.28^{\mathrm{a}}$ & $33.27 \pm 0.19^{\mathrm{a}}$ & $32.61 \pm 1.33^{\mathrm{a}}$ & $31.43 \pm 0.28^{\mathrm{a}}$ \\
Basil & $32.01 \pm 8.72^{\mathrm{a}}$ & $46.67 \pm 1.04^{\mathrm{c}}$ & $48.89 \pm 0.95^{\mathrm{c}}$ & $26.04 \pm 0.66^{\mathrm{b}}$ \\
White pepper & $6.48 \pm 0.10^{\mathrm{a}}$ & $15.73 \pm 0.10^{\mathrm{c}}$ & $9.77 \pm 0.38^{\mathrm{b}}$ & $6.95 \pm 0.76^{\mathrm{a}}$ \\
Njangsa & $9.43 \pm 0.28^{\mathrm{a}}$ & $18.27 \pm 0.10^{\mathrm{c}}$ & $16.00 \pm 1.61^{\mathrm{c}}$ & $13.79 \pm 0.38^{\mathrm{b}}$ \\
African nutmeg & $22.63 \pm 0.38^{\mathrm{a}}$ & $35.89 \pm 0.57^{\mathrm{c}}$ & $29.33 \pm 0.95^{\mathrm{b}}$ & $40.58 \pm 8.53^{\mathrm{c}}$ \\
\hline
\end{tabular}

Data with different superscripts are significant different $\mathrm{P}<0.05$, Student Newman Keul test.

Table 5. flavonoid content of spices or herbs.

\begin{tabular}{l|cccc}
\hline \multirow{2}{*}{ Sample } & \multicolumn{4}{|c}{ Flavonoids $(\mu \mathrm{g}$ quercetin equivalent /g of spice or herb) } \\
\cline { 2 - 5 } & Control & $65^{\circ} \mathrm{C}$ & $75^{\circ} \mathrm{C}$ & $85^{\circ} \mathrm{C}$ \\
\hline Mint & $9.71 \pm 0.48^{\mathrm{a}}$ & $28.31 \pm 2.87^{\mathrm{c}}$ & $20.64 \pm 0.96^{\mathrm{b}}$ & $16.47 \pm 0.48^{\mathrm{b}}$ \\
Parsley & $24.36 \pm 0.48^{\mathrm{a}}$ & $30.67 \pm 3.03^{\mathrm{b}}$ & $30.45 \pm 1.43^{\mathrm{b}}$ & $25.49 \pm 1.12^{\mathrm{a}}$ \\
Basil & $9.26 \pm 1.43^{\mathrm{a}}$ & $24.81 \pm 0.48^{\mathrm{c}}$ & $19.18 \pm 1.12^{\mathrm{b}}$ & $15.01 \pm 0.32^{\mathrm{b}}$ \\
White pepper & $3.18 \pm 0.16^{\mathrm{a}}$ & $10.28 \pm 0.96^{\mathrm{b}}$ & $21.43 \pm 0.48^{\mathrm{c}}$ & $10.73 \pm 0.32^{\mathrm{b}}$ \\
Njangsa & $2.73 \pm 1.16^{\mathrm{a}}$ & $5.88 \pm 0.48^{\mathrm{b}}$ & $5.32 \pm 0.64^{\mathrm{b}}$ & $3.85 \pm 0.16^{\mathrm{a}}$ \\
African nutmeg & $9.71 \pm 0.16^{\mathrm{a}}$ & $10.28 \pm 0.96^{\mathrm{a}}$ & $15.69 \pm 1.28^{\mathrm{b}}$ & $18.73 \pm 1.12^{\mathrm{b}}$ \\
\hline
\end{tabular}

Data with different superscripts are significant different $\mathrm{P}<0.05$, Student Newman Keul test.

Table 6. Vitamin $\mathrm{C}$ content of spices or herbs.

\begin{tabular}{l|cccc}
\hline \multirow{2}{*}{ Sample } & \multicolumn{4}{c}{ Vitamin $C(\mu \mathrm{g} / \mathrm{g}$ of spice or herb $)$} \\
\cline { 2 - 5 } & Control & $65^{\circ} \mathrm{C}$ & $75^{\circ} \mathrm{C}$ & $85^{\circ} \mathrm{C}$ \\
\hline Mint & $2500.00 \pm 0.00^{\mathrm{c}}$ & $1250 \pm 0.00^{\mathrm{b}}$ & $1041.67 \pm 294.63^{\mathrm{b}}$ & $729.17 \pm 147.31^{\mathrm{a}}$ \\
Parsley & $2500.00 \pm 3.15^{\mathrm{c}}$ & $1041.67 \pm 294.63^{\mathrm{b}}$ & $1041.67 \pm 294.63^{\mathrm{b}}$ & $666.67 \pm 235.70^{\mathrm{a}}$ \\
Basil & $1875.00 \pm 88.88^{\mathrm{c}}$ & $1250 \pm 7.88^{\mathrm{b}}$ & $729.17 \pm 147.31^{\mathrm{c}}$ & $562.50 \pm 88.39^{\mathrm{c}}$ \\
White pepper & $1250 \pm 7.880^{\mathrm{a}}$ & $1429.74 \pm 57.77^{\mathrm{b}}$ & $1776.961 \pm 433.28^{\mathrm{b}}$ & $1320.25 \pm 56.23^{\mathrm{a}}$ \\
Njangsa & $2500 \pm 0.00^{\mathrm{c}}$ & $1216.06 \pm 359.95^{\mathrm{b}}$ & $916.67 \pm 117.85^{\mathrm{b}}$ & $1100.01 \pm 52.12^{\mathrm{b}}$ \\
African nutmeg & $2500 \pm 0.00^{\mathrm{c}}$ & $1071.43 \pm 252.54^{\mathrm{a}}$ & $1488.10 \pm 841.79^{\mathrm{b}}$ & $731.17 \pm 127.31^{\mathrm{a}}$ \\
\hline
\end{tabular}

Data with different superscripts are significant different $\mathrm{P}<0.05$, Student Newman Keul test.

\section{Discussion}

Spices are vegetable ingredients that have been used since antiquity serving multi-purposes (Bhagya et al., 2017). In this study, results revealed that spices and herbs were mainly used for both flavoring and medicinal purposes which in line with the broaden use of spices in several regions around the world (De La Torre Torres et al., 2015). These traditional uses of spices are consistent with the literature though with development and technologies, there is more broaden uses of spices that includes flavouring and seasoning, indigenous medicines, pharmaceuticals, nutraceuticals, aroma therapy, preservatives, beverages, natural colours, perfumes, dental preparations, cosmetics and biopesticides. Spices thus, play a significant role in the economy of countries including Cameroon (Pavela et al., 2016; Bhagya et al., 2017; World Economic Forum, 2019). Spices and herbs were generally consumed in groups of five to six with the most used group being Parsley, Basil, White pepper, Njansa, Mint and African nutmeg. The preference for using the combination of spices or herbs could be due to certain search for more efficacy or complementarities of either seasoning, flavoring or medicinal effects of spices/herbs by the population. An ethnobotanical study in the Eastern Cape of South Africa also showed some level of preference of using mixture of spices for more potency by the local communities (Asowata-Ayodele et al., 2016).

One of the most aspects considered in using spices/herbs is the state either raw or cooked as this might not only affect the resulting flavor, taste of medicinal benefits, but the composition and content of secondary metabolites including antioxidants. The large portion of the participants consumed spices or herbs in their cooked form though the preference for the cooking state varied from moderate to high heat. The preference of cooked spices/herbs could be attributed to commonly use in 
culinary steps in local recipes and in traditional medical preparations such as infusion and decoction. This is consistent with the observation from the literature on the impact of processes prior to consumption of culinary herbs and spices (Opara and Chohan, 2014).

In order to assess the effect of common culinary process used by the populations on antioxidants, the most used or sold spices/ herbs were selected and submitted to different boiling temperatures adopted from the survey study. The temperature globally increased the release of total phenolics and flavonoids from spices/herbs, though highest temperature being less effective as compared to other temperatures. The moderate heating $\left(65^{\circ} \mathrm{C}\right)$ of spices/herbs samples induced the highest levels of these phytochemicals. Similarly, cooking leafy vegetables such as Olax zeylanica L. and Sesbania grandiflora (L.) Pers. on a moderate flame for $5 \mathrm{~min}$ showed significant higher polyphenol and flavonoid content as compared to the raw samples (Gunathilake et al., 2018). Also, increased yield of flavonoids was reported in boiled broccoli and spinach (Mazzeo et al., 2011). The increased of the phytochemicals in cooked samples could be attributed to the possible breakdown of the complex polyphenolic compounds such as tannins present in the vegetables during heat processing to simple polyphenols. Moreover, the heat treatments could inactivate polyphenol oxidases, preventing oxidation and polymerization of polyphenols (Yamaguchi et al., 2003; Gunathilake et al., 2018). However higher boiling temperatures $\left(75\right.$ and $85^{\circ} \mathrm{C}$ ) were detrimental to the phenolic and flavonoid content in spice and herb samples. These findings are in line with those of Azizah et al. (2009) who observed that boiling of pumpkin at high temperature $\left(100^{\circ} \mathrm{C}\right)$ for $2-6 \mathrm{~min}$ resulted in significant losses $(18.3 \%$ $53.8 \%$ ) of total phenolic compounds. Also heat treatments and cooking resulted in reduced polyphenolic levels in vegetables such as spinach, shallots, kale, swamp cabbage and cabbage (Ismail et al., 2004). This could be attributed to increase losses of these phytochemicals due to their leached into the cooking water with greater mobility at higher temperature or their relative instability to heat (Zhang and Hamauzu, 2004).

Vitamin $C$ levels of the investigated spices and green herbs were severely negatively affected by all the temperatures. Several studies have demonstrated the adverse effect of boiling temperature on vitamin $\mathrm{C}$ content of vegetables. Boiling green vegetables such as Xanthosoma sagittifolium (L.) Schott, Brassica oleracea L., Corchorus olitorius L. leaves, Solanum torvum Sw. and Abelmoschus esculentus (L.) Moench significantly decreased their vitamin C content (Agbemafle et al., 2012). Also, cooking broccoli, chard, mallow, carrots, sweet potato, crown daisy, perilla leaf and spinach for $5 \mathrm{~min}$ reduced vitamin $\mathrm{C}$ content as compared to the raw samples (Lee et al., 2018). Vitamin C is a water-soluble and a very heat-sensitive vitamin, and is therefore easily degraded during cooking (Igwemmar et al., 2013).

Spices and herbs constitute a group of vegetables with valuable antioxidant properties with subsequent applications on human health and food industries. However, they are preferably consumed cooked or in cooked or processed recipes. A high temperature can inactivate microorganisms, decrease anti-nutritional factors, Increase the digestibility of foods, and modify the bioavailability of the phytochemicals including phenolics, flavonoids and vitamins. On the other hand, cooking changes the sensorial, nutritional and textural qualities of spices which may affect the quantity and quality of bioactive compounds, such as antioxidants (Minatel et al., 2017). The high phenolic and flavonoid content of green herbs and spices, essentially after boiling at $65^{\circ} \mathrm{C}$ supports possible beneficial effect of this temperature to increase the bioavailability of phytochemicals in vegetables. However, the adverse effect of this temperature on vitamin $C$, though minimal with respect to other boiling temperatures, points out a certain balance that should be considered between the interest in this vitamin and other phytochemicals in the search of bioactive molecules from spices and green herbs.

In conclusion, this study revealed the use of spices and green herbs by the local populations and the positive effect of boiling these vegetables at $65^{\circ} \mathrm{C}$ for higher availability of total phenolics and flavonoids. The use of such thermal treatment by the population for cooking spices/ green herbs should be encouraged though raw preparations should be preferred when interested in heat-labile antioxidants such as vitamin $\mathrm{C}$.

\section{Acknowledgments}

The authors express their gratitude to all spices/herbs consumers and sellers who participated in the study.

\section{Conflict of Interest}

The authors declared no conflicts of interest with respect to the research, authorship, and/or publication of this article.

\section{References}

Adamson WM, 2004. Food in Medieval Times. Westport, Greenwood Press. ISBN 0-313-32147-7

Agbemafle R, Obodai AE, Adukpo EG, Amprako ND. 2012. Effects of boiling time on the concentrations of vitamin $\mathrm{C}$ and betacarotene in five selected green vegetables consumed in Ghana. Advances in Applied Science Research, 3(5): 2815-2820.

Asowata-Ayodele MA, Afolayan JA, Otunola AG. 2016. Ethnobotanical survey of culinary herbs and spices used in the traditional medicinal system of Nkonkobe Municipality, Eastern Cape, South Africa. South African Journal of Botany, 104: 69-75.

Azizah AH, Wee KC, Azizah O, Azizah M. 2009. Effect of boiling and stir frying on total phenolics, carotenoids and radical scavenging activity of pumpkin (Cucurbita moschato). International Food Research Journal, 16: 45-51.

Bhagya HP, Raveendra YC, Lalithya KA. 2017. Mulibenificial Uses of Spices: A Brief Review. Acta Scientific Nutritional Health, 1(1): 03-06.

EUFIC, 2010. European Food Information Council. Why Do We Cook Our Food and What Happens When We Do? https://www.eufic.org/en/food-safety/article/the-why-howand-consequences-of-cooking-our-food [Accessed 13 October 2020]

Gottardi D, Bukvicki D, Prasad S, Tyagi AK. 2016. Beneficial Effects of Spices in Food Preservation and Safety. Frontiers in Microbiology, 7: 1394. doi: 10.3389/fmicb.2016.01394.

Gunathilake PPDK, Ranaweera SDKK, Rupasinghe VPH. 2018. Effect of Different Cooking Methods on Polyphenols, Carotenoids and Antioxidant Activities of Selected Edible Leaves. Antioxidants, 7: 117. doi:10.3390/antiox7090117. 
Mastura HY, Hasnah H, Yap YT. 2017. Total phenolic content and antioxidant capacities of instant mix spices cooking pastes. International Food Research Journal, 24(1): 68-74.

Habwe OF, Walingo MK. 2008. Food Processing and Preparation Technologies for Sustainable Utilization of African Indigenous Vegetables for Nutrition Security and Wealth Creation in Kenya. In: Robertson GL, Lupien JR (Editors). Using Food Science and Technology to Improve Nutrition and Promote National Development, International Union of Food Science and Technology. pp.1-9.

Hwang ES. 2017. Influence of Cooking Methods on Bioactive Compound Content and Antioxidant Activity of Brussels Sprouts. Preventive Nutrition and Food Science, 22(4):353-358.

Igwemmar CN, Kolawole AS, Imran AI. 2013. Effect of heating on vitamin $\mathrm{C}$ content of some selected vegetables. International Journal of Scientific and Technology Research, 2(11): 209-212.

Ismail A, Marjan ZM, Foong CW. 2004. Total antioxidant activity and phenolic content in selected vegetables. Food Chemistry, 87: 581-586.

De La Torre Torres EJ, Gassara F, Kouassi PA, Brar KS, Belkacemi K. 2015. Spice Use in Food: Properties and Benefits. Critical Reviews in Food Science and Nutrition, doi: http://dx.doi.org/10.1080/10408398.2013.858235.

Karimian-khosroshahi N, Hosseini H, Rezaei M, Khaksar R, Mahmoudzadeh M. 2015. Effect of different cooking methods on minerals, vitamins, and nutritional quality indices of rainbow trout (Oncorhynchus mykiss). International Journal of Food Properties, 19(11): 2471-2480.

Lee JW. 2019. Vitamin C in Human Health and Disease Effects, Mechanisms of Action, and New Guidance on Intake. Springer Nature BV. ISBN 978-94-024-1711-1.

Lee S, Choi Y, Jeong SH, Lee J, Sung J. 2018. Effect of different cooking methods on the content of vitamins and true retention in selected vegetables. Food Science and Biotechnology, 27(2):333-342.

Lourenço CS, Moldão-Martins M, Alves DV. 2019. Antioxidants of Natural Plant Origins: From Sources to Food Industry Applications. Molecules, 24(22): 4132; https://doi.org/ $10.3390 /$ molecules 24224132

Mazzeo T, N'Dri D, Chiavaro E, Visconti A, Fogliano V, Pellegrini N. 2011. Effect of two cooking procedures on phytochemical compounds, total antioxidant capacity, and color of selected frozen vegetables. Food Chemistry, 128: 627-633.

Miglio C, Chiavaro E, Visconti A, Fogliano V, Pellegrini N. 2007. Effects of different cooking methods on nutritional and physicochemical characteristics of selected vegetables. Journal of Agricultural and Food Chemistry, 56: 139-147.

Minatel OI, Borges VC, Ferreira IM, Gomez GAH, Chen OC-Y, Lima PPG. 2017. Phenolic Compounds: Functional Properties, Impact of Processing and Bioavailability. In: Soto-Hernández S, Palma-Tenango M, García-Mateos R (Editors), Phenolic compounds, London, IntehOpen. ISBN: 978-953-51-2960-8.

Mohammed FS, Karakaş M, Akgül H, Sevindik M. 2019. Medicinal Properties of Allium calocephalum Collected from Gara Mountain (Iraq). Fresenius Environmental Bulletin, 28(10): 7419-7426.

Mohammed FS, Şabik AE, Sevindik E, Pehlivan M, Sevindik M. 2020. Determination of Antioxidant and Oxidant Potentials of Thymbra spicata Collected from Duhok-Iraq. Turkish Journal of Agriculture-Food Science and Technology, 8(5): 1171-1173.
Nantia AE, Soh D, Choumessi TA, Ngum NNM, Chi HAN, Kenfack A. 2018. In vitro antioxidant property of the methanol extracts of the whole plant and fruit of Momordica foetida (Cucurbitaceae). The Pharmaceutical and Chemical Journal, 5(6): 117-125.

Ozcan T, Akpinar-Bayizit A, Yilmaz-Ersan L, Delikanli B. 2014. Phenolics in Human Health. International Journal of Chemical Engineering and Applications, 5(5):393-396.

Opara IE, Chohan M. 2014. Culinary Herbs and Spices: Their Bioactive Properties, the Contribution of Polyphenols and the Challenges in Deducing Their True Health Benefits. International Journal of Molecular Sciences, 15: 1918319202.

Pavela R, Maggi F, Mbuntcha H, Woguem V, Fogang DPH, Womeni MH, Léon Azefack Tapondjou AL, Barboni L, Nicoletti M, Canale A, Benelli G. 2016. Traditional herbal remedies and dietary spices from Cameroon as novel sources of larvicides against filariasis mosquitoes? Parasitology Research, 115: 4617-4626.

Pehlivan M, Mohammed FS, Sevindik M, Akgul H. 2018. Antioxidant and oxidant potential of Rosa canina. Eurasian Journal of Forest Science, 6(4): 22-25.

Peter VK. 2012. Handbook of herbs and spices. In: Peter VK (editor). Introduction to herbs and spices: definitions, trade and applications. Second edition, Volume 1. Oxford. pp.1-24. ISBN 978-0-85709-039-3 (print) ISBN 978-0-85709-567-1 (online)

Sarkar A. 2016. Natural Antioxidants - The Key to Safe and Sustainable Life. International Journal of Latest Trends in Engineering and Technology, 6(3): 460-466.

Sevindik M, Akgul H, Pehlivan M, Selamoglu Z. 2017. Determination of therapeutic potential of Mentha longifolia ssp. longifolia. Fresenius Environmental Bulletin, 26(7): 4757-4763.

Shahbandeh M. 2020. Estimated value of spices markets worldwide from 2019 to 2025 (in billion U.S. dollars). https://www.statista.com/statistics/876234/global-seasoningand-spices-market-size/ [Accessed 13 October 2020]

Song J-F, Liu C-Q, Li D-J, Meng L-L. 2013. Effect of cooking methods on total phenolic and carotenoid amounts and DPPH radical scavenging activity of fresh and frozen sweet corn (Zea mays) kernels. Czech Journal of Food Sciences, 31: 607-612.

World Economic Forum. 2019. Cameroon farmers spice up earnings with forest-friendly foods https://www.weforum. org/agenda/2019/04/cameroon-farmers-spice-up-earningswith-forest-friendly-foods [Accessed 13 October 2020]

Yamaguchi T, Katsuda M, Oda Y, Terao J, Kanazawa K, Oshima S, Inakuma T, Ishiguro Y, Takamura H, Matoba T. 2003. Influence of polyphenol and ascorbateoxidases during cooking process on the radical-scavenging activity of vegetables. Food Science and Technology Research, 9: 7983.

Yashin A, Yashin Y, Xia X, Nemzer B. 2017. Antioxidant Activity of Spices and Their Impact on Human Health: A Review. Antioxidants, 6(3): 70; https://doi.org/10.3390/antiox6030070.

Zhang D, Hamauzu Y. 2004. Phenolics, ascorbic acid, carotenoids and antioxidant activity of broccoli and their changes during conventional and microwave cooking. Food Chemistry, 88: 503-509. 